\title{
CELL-MOLECULAR MECHANISMS OF PROGRESSION OF OPHTHALMOLOGICAL PATHOLOGY ON THE BACKGROUND OF INFLUENCE OF ENVIRONMENTAL FACTORS. LITERATURE REVIEW
}

\author{
O. Nedzvetska, I. Bagmut, I. Soboleva, I. Pastukh, N. Goncharova
}

\begin{abstract}
Modern scientists are increasingly paying attention to the molecular mechanisms of diseases of the visual organ in conditions of anthropogenic pollution. Environmental pollution is mainly due to atmospheric emissions from the metallurgical, automotive, aviation and petrochemical industries, waste from livestock farms and due to the use of mineral fertilizers and pesticides. Ukraine ranks one of the first in Europe in terms of the amount of industrial dirt per capita.

The aim of this literature review was to analyze the role of extra-and intracellular protein structures and molecular mechanisms of some pathological processes of the visual organ that occur under the influence of anthropogenic stress on the human body.
\end{abstract}

Material and methods. Scientific publications in foreign and Ukranian journals on relevant topics in the last 5 years, the Internet resources.

Research results and their discussion. The literature review expanded the scientific understanding of the role of reparative enzyme (MGMT), vascular endothelial growth factor, Bcl-2 family proteins, p53 and Ki 67 proteins, matrix metalloproteinases in some ophthalmic pathology. Anthropoecological environmental factors have been shown to cause oxidative stress due to mitochondrial dysfunction and apoptosis, which are a component of a complex pathophysiological process in the most common diseases of the visual analyzer.

Conclusions. The study of molecular mechanisms of occurrence and progression of diseases of the visual organ with the participation of protein factors makes it possible to expand the understanding of the pathogenetic links of their development in order to predict the course of the pathological process, adequate treatment and prevention

Keywords: pathological processes of the organ of vision, matrix metalloproteinases, cytokines, vascular endothelial growth factor, 553 protein, heavy metals

Copyright (C) 2021, O. Nedzvetskaya, I. Bagmut, I. Soboleva, I. Pastukh, N. Goncharova.

This is an open access article under the CC BY license (http://creativecommons.org/licenses/by/4.0).

\section{Introduction}

In Ukraine, there is an annual increase in the incidence and prevalence of diseases of the eye and its appendages (H00-H59) among people of working age [1]. According to world statistics, at least 2.2 billion people worldwide suffer from severe visual impairment or blindness [2]. Along with the main etiological factors of ophthalmic pathology, special attention is drawn to the deterioration of the environmental situation, which can serve as a trigger for the emergence of this nosology [3, 4]. Thus, according to Amirov A. N. and co-authors [5, 6] the prevalence of refractive errors, inflammatory diseases of the conjunctiva and eyelids in children living in areas with heavy traffic is higher than in areas with favorable environmental conditions. The pathology of the lens was more often observed in the population living with adjacent enterprises for the production of film. In patients with dry eye syndrome, scientists have found elevated levels of mercury in the serum [7].

Diseases of the visual organ reduce the quality of life of patients, and in some cases not only impair visual function, but also cause vision loss. Therefore, ensuring the normal functioning and prevention of pathological conditions of the visual analyzer in conditions of high anthropogenic load, is the primary and most urgent task today.

The aim of the literature review was to analyze the role of extra- and intracellular protein structures and molecular mechanisms of some pathological processes of the visual organ that occur under the influence of anthropogenic stress on the human body.

\section{Materials and methods}

In writing the article, information from domestic and foreign (electronic database Pub Med) scientific publications for the last 5 years was used.

\section{Research results}

Pathology of the visual analyzer may be the result of congenital or acquired genetic abnormalities in the human body. Exo - and endogenous environmental factors affect the human genome, contributing to damage to DNA structure. The crucial role in this case is given to one of the DNA repair enzymes $-\mathrm{O}^{6}$-methylguanineDNA methyltransferase (MGMT), which protects cells from the cytotoxic action of alkylating compounds [8], by transferring the alkylating group (mostly metal) from the $\mathrm{O}^{6}$ position of guanine $\left(\mathrm{O}^{6} \mathrm{MeG}\right)$ of the DNA 
molecule to the cysteine of the active center of the enzyme, and then irreversibly inactivated [9].

In normal cells of the human body, the level of MGMT expression depends on their type, it is not stable and varies in different individuals. Regulation of MGMT gene expression is carried out by various intracellular systems, including and p53 protein-mediated [10]. Especially low expression of reparative enzyme in brain tissues [11]. Some metal ions $-\mathrm{Cd}^{2+}, \mathrm{Cu}^{2+}, \mathrm{Hg} 2+, \mathrm{Zn}^{2+}$, $\mathrm{Ag}^{2+}$ and $\mathrm{Pb}^{2+}$ inhibit the activity of MGMT [12]. Yazici H. and co-authors [13] in their work proved that functional inactivation of the reparative enzyme $\mathrm{O}^{6} \mathrm{MeG}$ in children with retinoblastoma causes damage to the DNA structure due to hypermethylation of the promoter part of the RASSF1A gene in $82 \%$ of cases. A similar mechanism of blocking the MGMT gene by alkylating agents in the epithelium of the lens of the eye in patients with age-related cataracts is described by $\mathrm{Li} \mathrm{F}$. and coauthors [14].

Among many diseases of the retina, optic nerve and auxiliary apparatus of the eye, one of the most important pathogenetic factors is the accumulation of free radicals and impaired antioxidant protection. Oxidative stress caused by heavy metals, pesticides, UV rays, ionizing radiation triggers the mechanism of apoptosis (through the expression of proteins p53, FasR, caspase-3) in photoreceptor cells, the most vulnerable to the damaging agent, which leads to loss of functional activity of the retina [15]. In an oxygen-induced retinopathy model in rats, the antiapoptotic effect of peroxisome proliferatoractivated receptor alpha (PPAR- $\alpha$ ) has been demonstrated. This protective mechanism is partially mediated by a decrease in the expression of Hif- $1 \alpha$ / Nox 4 (Nicotine adenine dinucleotide phosphate oxidase-4) and the levelling of the toxic effects of reactive oxygen species $[16,17]$. All isoforms of PPARs - PPAR $\alpha, \operatorname{PPAR} \beta$ / b1, PPAR $\beta$ / b2, PPAR $\gamma 1$ and PPAR $\gamma 2$, and some of them in all layers of the retina were detected in the pigment epithelial cells. Activation of PPAR $\beta$ / $\delta$ by PPAR $\beta$ / $\delta$ agonists has been shown to block VEGF-induced retinal vascular endothelial cell proliferation by reducing the expression of VEGFR2 receptor VEGF (Vascular endothelial growth factor). Thus, the process of neovascularization and the development of exudative retinopathy is inhibited.

One of the main factors in the initialization of vascular endothelial growth factor production in agerelated macular degeneration [18], diabetic retinopathy [19], postthrombotic retinopathy [20] is damage to retinal endothelial vessels due to oxidative stress, which causes the death of pericytes, hyperfiltration of plasma and blood cells and leads to retinal hypoxia. Pathological angiogenesis eventually leads to the formation of edema, hemorrhage into the retina and its detachment. The decrease in the activity of antioxidant systems under oxidative stress may be due to the inhibition of enzymes by heavy metal ions in the competition for the active center of the molecule.

After experimental studies [21], the moleculargenetic theory of glaucomatous optic neuropathy becomes relevant, the key point of which is apoptosis of ganglion cells of the optic nerve and retina due to in- creased expression of endogenous inducers of apoptosis and deficiency of neurotransmitters [22].

Under the conditions of activation of the p53 protein of the mitochondrial pathway of apoptosis [23], the membrane potential of mitochondria in the cell decreases, the permeability of its membrane increases with the formation of pores and the release of apoptogenic factors - cytochrome C, procaspase-3, 7, 9 the final stage of which is chromosome defragmentation and cell death [24]. Regulation of mitochondrial membrane permeability is provided by the balance of interaction of proteins of the family (Bcell lymphoma 2). Today, more than 20 members of this family are known, some of which are proapoptogenic - Wah, Bid, Bac, Vok, Bad, BclxS, Bim, Bik, Blk, Hrk (localized mainly in the cytosol), others are located in the outer membrane of mitochondria and endoplasmic reticulum and are antiapoptogenic - Bcl-2, Bcl-XL, Bcl-w, McU, Bfll [25]. The antiapoptotic role of $\mathrm{Bcl}-2$ proteins is associated with the ability of Bcl-2, Bcl-lx molecules to block mitochondrial channels, in contrast to Bax and Bak, through which the release of cytochrome $\mathrm{C}$ and AIF, and prevent the conversion of procaspase- 9 to the active form, thereby turning off the apoptosis signal.

The p53 protein has been shown to increase the expression of the proapoptogenic Bax gene and to reduce the expression of the Bcl-2 gene, which blocks apoptosis [26]. Level p53, Bcl-2 and caspase -3, -8, -9 [27] were significantly higher in the epithelial cells of the lens in patients with cataracts on the background of type 2 diabetes, which confirms the literature regarding their participation in the activation of the internal mechanism of apoptosis and the development of the pathological process.

At the present stage of development of medical science, many theories of glaucoma development have been put forward, each of which complements and expands our understanding of the etiopathogenesis of optic neuropathy. The immune mechanisms of glaucomatous process development deserve attention [28], because it is the immune system that ensures the normal operation of the visual analyzer by preserving the antigenic constancy of the microstructures of the visual organ and its functional components.

But, recently, on the literary scientific platform there are works, the authors of which found an increased content of lead in patients with open-angle glaucoma [29]. Selenium increases the risk of glaucoma and ophthalmic hypertension in patients who have used it as a dietary supplement [30]. Scientists attribute this fact to an imbalance in the synthesis of metalloproteinases (MMP-2) and their inhibitors.

Matrix metalloproteinases (MMPs) - a family of extracellular zinc and calcium-dependent endopeptidases capable of destroying collagen types IV, V, VII, IX, X (the main component of the basement membrane, fibroconnective membrane of the eye and cornea), proteoglycans, lactylamine, elastin other components of the extracellular matrix of connective tissue in normal and in pathology [31]. According to the specificity of MMP 
can be divided into collagenases (MMP-1, -8 and -13), gelatinase (MMP-2 and -9), stromelysin (MMP-3 and -10), membrane type MMP - (MT-MMP-14, -15, -16, -17) and other types, including matrilysin (MMP-7) and metalloelastase (MMP-12).

MMPs are "induced" proteins whose synthesis is controlled by a number of factors: interleukins (IL-1, IL-4, IL-6), tumour necrosis factor (TNF), transforming growth factors (TGF- $\beta 1$ ), hormones, tumour promoters, physical compounds and under normal conditions, the regulation of MMP activity occurs due to specific endogenous tissue inhibitors TIMPs (tissue inhibitor of matrix metalloproteinase 1-4), which block the destruction of the extracellular matrix. Namely, the imbalance between the level of expression of MMP and TIMPs, play a major role in the pathogenesis of not only glaucoma, but also diabetic retinopathy, age-related macular degeneration [32].

In primary open-angle glaucoma (POAG), metalloproteinases are synthesized in various structures of the eye - the tenon capsule, trabecular system, Schlemm's canal, scleral lattice plate and retinal ganglion cells [33]. An experimental study of MMP-2,9 in the tears of patients with POAG, found a significant increase in their activity compared with the control group. The direct correlation between the level of MMP-9 and the stage of the disease, according to the authors, may serve as a criterion for the progression of glaucomatous process, and the expression of MMP-2 is a compensatory response to inflammation in ECM degradation [34]

During a comprehensive immunohistochemical study of the connective tissue of the sclera in POAG revealed an intensive accumulation of uncharacteristic type III collagen, which may indirectly indicate a violation of the metabolism of various types of MMPs in the pathological process [35].

In the study of immune status in patients with POAG, high levels of proinflammatory cytokines - IL-6, IL-17 and low values - TGF- $\beta_{1}$ and TGF- $\beta_{3}$, both in systemic and in tears, which confirms the autoimmune theory of ECM damage with the development of chronic inflammatory process.

In the aqueous humor of the anterior chamber, patients with pseudo exfoliative syndrome / glaucoma (PES / PEG), high rates of MMP-2, TIMP-2 та TGF- $\beta_{1}$ were detected [36].

The accumulation of the extracellular matrix, rather than its degradation in patients with POAG and PEG, according to scientists, occurs due to elevated levels of
TIMP-2 over MMP-2. In addition, some authors noted that the pathological remodelling of the lattice plate of the sclera under the influence of MMP in patients with glaucoma, there is a loss of neural tissue, rather than its scarring [37, 38]. Apparently, this fact can explain the development of glaucomatous excavation of the optic disc in glaucoma with normal intraocular pressure.

According to the literature, in most cases, the development of the primary pterygium is preceded by pinguecula. In our opinion, this is not unfounded, as overexpression of MMP family proteins by subepithelial fibroblasts of the bulbar conjunctiva of the eye disrupts the fragmentation and organization of collagen fibers of the Bowman's membrane and corneal stroma, which promotes migration and invasion of pinguecula cells.

One of the markers of cell proliferation is the expression of the Ki 67 protein, which is present in the cell nucleus during the G1, S, and G2 phases of the cell cycle and in mitosis. It does not accumulate or appear in cells in the interphase, due to the rapid, within 1-2 hours, destruction after synthesis. A possible role of Ki 67 in a cell is chromatin binding, which may play a role in cell division [39].

In ophthalmology, the Ki 67 antigen is used as a reliable marker of proliferative activity in neoplasms of the eyeball and its appendages, pathologies of the cornea and conjunctiva $[40,41]$.

As factors of immunological protection immunoglobulins IgM and IgG in ophthalmology are described in viral, bacterial, autoimmune processes, but data on their activity in the structures of the eye under the influence of heavy metals in the literature are not found, which is a necessary argument for further study.

\section{Conclusions}

1. Environmental factors, in particular heavy metals, can affect the processes of repair inside the cell and contribute to the progression of existing ophthalmic pathology.

2. The study of molecular mechanisms of occurrence and progression of diseases of the visual organ with the participation of protein factors makes it possible to expand the understanding of pathogenetic links of their development in order to predict the course of the pathological process, adequate treatment and prevention.

\section{Conflict of interests}

The authors declare there is no conflict of interests.

\section{References}

1. Khvesyk, M. A.; Khvesyk, M. A. (Ed.) (2014) .Ekolohichna i pryrodno-tekhnohenna bezpeka Ukrainy v rehionalnomu vymiri. Kyiv: In-t ekonomiky pryrodokorystuvannia ta staloho rozvytku, 339.

2. Yakovenko, O. V., Kuraieva, I. V., Kroik, H. A. et. al. (2015). Heokhimichni osoblyvosti rozpodilu vazhkykh metaliv u gruntakh zony vplyvu pidpryiemstv kolorovoi metalurhii. Visnyk Dnipropetrovskoho universytetu. Seriia: Heolohiia, heohrafiia, 23 (1), 152-157.

3. Kuraeva, Y. V. (2016). Geochemical indicators of the ecological state of the contaminated soil. Dnipropetrovsk University Bulletin. Series: geology, geography, 24 (2), 61-69. doi: http://doi.org/10.15421/111634

4. Fu, Z., Xi, S. (2019). The effects of heavy metals on human metabolism. Toxicology Mechanisms and Methods, 30 (3), 167-176. doi: http://doi.org/10.1080/15376516.2019.1701594

5. Le, D.-V., Jiang, J.-H. (2020). Fluorescence determination of the activity of O6-methylguanine-DNA methyltransferase based on the activation of restriction endonuclease and the use of graphene oxide. Microchimica Acta, 187 (5). doi: http://doi.org/10.1007/s00604-020-04280-0 
6. Xing, X., He, Z., Wang, Z., Mo, Z., Chen, L., Yang, B. et. al. (2020). Association between H3K36me3 modification and methylation of LINE-1 and MGMT in peripheral blood lymphocytes of PAH-exposed workers. Toxicology Research, 9 (5), 661668. doi: http://doi.org/10.1093/toxres/tfaa074

7. Wang, K., Chen, D., Qian, Z., Cui, D., Gao, L., Lou, M. (2017). Hedgehog/Gli1 signaling pathway regulates MGMT expression and chemoresistance to temozolomide in human glioblastoma. Cancer Cell International, 17 (1). doi: http://doi.org/10.1186/s12935-017-0491-x

8. Yu, W., Zhang, L., Wei, Q., Shao, A. (2020). O6-Methylguanine-DNA Methyltransferase (MGMT): Challenges and New Opportunities in Glioma Chemotherapy. Frontiers in Oncology, 9. doi: http://doi.org/10.3389/fonc.2019.01547

9. Njuma, O. J., Su, Y., Guengerich, F. P. (2019). The abundant DNA adduct N7-methyl deoxyguanosine contributes to miscoding during replication by human DNA polymerase $\eta$. Journal of Biological Chemistry, 294 (26), 10253-10265. doi: http://doi.org/10.1074/jbc.ra119.008986

10. Yazici, H., Wu, H., Tigli, H., Yilmaz, E., Kebudi, R., Santella, R. (2020). High levels of global genome methylation in patients with retinoblastoma. Oncology Letters, 20 (1), 715-723. doi: http://doi.org/10.3892/ol.2020.11613

11. Li, P., Yu, H., Zhang, G., Kang, L., Qin, B., Cao, Y. et. al. (2020). Identification and Characterization of N6Methyladenosine CircRNAs and Methyltransferases in the Lens Epithelium Cells From Age-Related Cataract. Investigative Opthalmology \& Visual Science, 61 (10), 13. doi: http://doi.org/10.1167/iovs.61.10.13

12. Vynohradova, Yu. V. (2015). Issledovanye povrezhdenyia y protsessov vosstanovlenyia setchatky hlaza mishei posle obluchenyia uskorennimy protonamy i deistvyia metylnytrozomochevyni. Dubna, 23.

13. Deng, G., Moran, E. P., Cheng, R., Matlock, G., Zhou, K., Moran, D. et. al. (2017). Therapeutic Effects of a Novel Agonist of Peroxisome Proliferator-Activated Receptor Alpha for the Treatment of Diabetic Retinopathy. Investigative Opthalmology \& Visual Science, 58 (12), 5030-5042. doi: http://doi.org/10.1167/iovs.16-21402

14. Savage, S. R., McCollum, G. W., Yang, R., Penn, J. S. (2015). RNA-seq identifies a role for the PPAR $\beta / \delta$ inverse agonist GSK0660 in the regulation of TNF $\alpha$-induced cytokine signaling in retinal endothelial cells. Molecular Vision, 21, 568-576.

15. Zografos, L. J., Andrews, E., Wolin, D. L., Calingaert, B., Davenport, E. K., Hollis, K. A. et. al. (2019). Physician and Patient Knowledge of Safety and Safe Use Information for Aflibercept in Europe: Evaluation of Risk-Minimization Measures. Pharmaceutical Medicine, 33 (3), 219-233. doi: http://doi.org/10.1007/s40290-019-00279-y

16. Romero-Aroca, P., Baget-Bernaldiz, M., Pareja-Rios, A., Lopez-Galvez, M., Navarro-Gil, R., Verges, R. (2016). Diabetic Macular Edema Pathophysiology: Vasogenic versus Inflammatory. Journal of Diabetes Research, 2016, 1-17. doi: http://doi.org/10.1155/2016/2156273

17. Shalchi, Z., Mahroo, O., Bunce, C., Mitry, D. (2020). Anti-vascular endothelial growth factor for macular oedema secondary to branch retinal vein occlusion. Cochrane Database of Systematic Reviews, 7 (7). doi: http://doi.org/10.1002/14651858.cd009510.pub3

18. Joseph, C., Mangani, A. S., Gupta, V., Chitranshi, N., Shen, T., Dheer, Y. et. al. (2020). Cell Cycle Deficits in Neurodegenerative Disorders: Uncovering Molecular Mechanisms to Drive Innovative Therapeutic Development. Aging and Disease, 11 (4), 946-466. doi: http://doi.org/10.14336/ad.2019.0923

19. Shpak, A. A., Guekht, A. B., Druzhkova, T. A., Kozlova, K. I., Gulyaeva, N. V. (2017). Brain-Derived Neurotrophic Factor in Patients with Primary Open-Angle Glaucoma and Age-related Cataract. Current Eye Research, 43 (2), $224-231$. doi: http://doi.org/10.1080/02713683.2017.1396617

20. Awais, R., Spiller, D. G., White, M. R. H., Paraoan, L. (2016). p63 is required beside p53 for PERP-mediated apoptosis in uveal melanoma. British Journal of Cancer, 115 (8), 983-992. doi: http://doi.org/10.1038/bjc.2016.269

21. Xiao, F., Li, Y., Dai, L., Deng, Y., Zou, Y., Li, P. et. al. (2012). Hexavalent chromium targets mitochondrial respiratory chain complex I to induce reactive oxygen species-dependent caspase-3 activation in L-02 hepatocytes. International Journal of Molecular Medicine, 30 (3), 629-635. doi: http://doi.org/10.3892/ijmm.2012.1031

22. Naoi, M., Wu, Y., Shamoto-Nagai, M., Maruyama, W. (2019). Mitochondria in Neuroprotection by Phytochemicals: Bioactive Polyphenols Modulate Mitochondrial Apoptosis System, Function and Structure. International Journal of Molecular Sciences, 20 (10), 2451. doi: http://doi.org/10.3390/ijms20102451

23. Boutry, J., Dujon, A. M., Gerard, A.-L., Tissot, S., Macdonald, N., Schultz, A. et. al. (2020). Ecological and Evolutionary Consequences of Anticancer Adaptations. iScience, 23 (11), 101716. doi: http://doi.org/10.1016/j.isci.2020.101716

24. Ahn, Y. J., Kim, M. S., Chung, S. K. (2016). Calpain and Caspase-12 Expression in Lens Epithelial Cells of Diabetic Cataracts. American Journal of Ophthalmology, 167, 31-37. doi: http://doi.org/10.1016/j.ajo.2016.04.009

25. Chitranshi, N., Dheer, Y., Abbasi, M., You, Y., Graham, S. L., Gupta, V. (2018). Glaucoma Pathogenesis and Neurotrophins: Focus on the Molecular and Genetic Basis for Therapeutic Prospects. Current Neuropharmacology, 16 (7), 1018-1035. doi: http://doi.org/10.2174/1570159x16666180419121247

26. Vennam, S., Georgoulas, S., Khawaja, A., Chua, S., Strouthidis, N. G., Foster, P. J. (2019). Heavy metal toxicity and the aetiology of glaucoma. Eye, 34 (1), 129-137. doi: http://doi.org/10.1038/s41433-019-0672-z

27. Conley, S. M., McKay, B. S., Jay Gandolfi, A., Daniel Stamer, W. (2006). Alterations in human trabecular meshwork cell homeostasis by selenium. Experimental Eye Research, 82 (4), 637-647. doi: http://doi.org/10.1016/j.exer.2005.08.024

28. Vafadari, B., Salamian, A., Kaczmarek, L. (2016). MMP-9 in translation: from molecule to brain physiology, pathology, and therapy. Journal of Neurochemistry, 139, 91-114. doi: http://doi.org/10.1111/jnc. 13415

29. Singh, M., Tyagi, S. C. (2017). Metalloproteinases as mediators of inflammation and the eyes: molecular genetic underpinnings governing ocular pathophysiology. International Journal of Ophthalmology, 10 (8), 1308-1318. doi: http://doi.org/10.18240/ijo.2017.08.20

30. O'Callaghan, J., Cassidy, P. S., Humphries, P. (2017). Open-angle glaucoma: therapeutically targeting the extracellular matrix of the conventional outflow pathway. Expert Opinion on Therapeutic Targets, 21 (11), 1037-1050. doi: http://doi.org/10.1080/ 14728222.2017.1386174

31. Levanova, O. N., Sokolov, V. A., Likhvantseva, V. G. i dr. (2017). Korreliatsionnii analiz klinicheskikh, morfometricheskikh i funktsionalnykh pokazatelei s matriksnymi metalloproteinazami-2 i -9 pri pervichnoi otkrytougolnoi glaukome. Prakticheskaia meditsina, 3 (104), 54-59.

32. Zhuravleva, A. N. (2010). Skleralnii komponent v glaukomnom protsesse. Moscow, 26.

33. Määttä, M., Tervahartiala, T., Harju, M., Airaksinen, J., Autio-Harmainen, H., Sorsa, T. (2005). Matrix Metalloproteinases and Their Tissue Inhibitors in Aqueous Humor of Patients With Primary Open-Angle Glaucoma, Exfoliation Syndrome, and Exfoliation Glaucoma. Journal of Glaucoma, 14 (1), 64-69. doi: http://doi.org/10.1097/01.ijg.0000145812.39224.0a 
34. Schneider, M., Fuchshofer, R. (2016). The role of astrocytes in optic nerve head fibrosis in glaucoma. Experimental Eye Research, 142, 49-55. doi: http://doi.org/10.1016/j.exer.2015.08.014

35. Feng, Q. Y., Hu, Z. X., Song, X. L., Pan, H. W. (2017). Aberrant expression of genes and proteins in pterygium and their implications in the pathogenesis. International Journal of Ophthalmology, 10 (6), 973-981. doi: http://doi.org/10.18240/ijo.2017.06.22

36. Belinsky, I., Murchison, A. P., Evans, J. J., Andrews, D. W., Farrell, C. J., Casey, J. P. et. al. (2018). Spheno-Orbital Meningiomas: An Analysis Based on World Health Organization Classification and Ki-67 Proliferative Index. Ophthalmic Plastic \& Reconstructive Surgery, 34 (2), 143-150. doi: http://doi.org/10.1097/iop.0000000000000904

37. Su, F. F., Chen, J. L. (2019). Expression and clinical significance of p16 and Ki-67 in malignant melanoma of the conjunctiva. Journal of Biological Regulators and Homeostatic Agents, 33 (3), 821-825.

38. Turan, M., Turan, G. (2020). Bcl-2, p53, and Ki-67 expression in pterygium and normal conjunctiva and their relationship with pterygium recurrence. European Journal of Ophthalmology, 30 (6), 1232-1237. doi: http://doi.org/10.1177/1120672120945903

39. Rahimi-Esboei, B., Zarei, M., Mohebali, M., Keshavarz Valian, H., Shojaee, S., Mahmoudzadeh, R., Salabati, M. (2018). Serologic Tests of IgG and IgM Antibodies and IgG Avidity for Diagnosis of Ocular Toxoplasmosis. The Korean Journal of Parasitology, 56 (2), 147-152. doi: http://doi.org/10.3347/kjp.2018.56.2.147

40. Yip, C., Foidart, P., Noël, A., Sounni, N. (2019). MT4-MMP: The GPI-Anchored Membrane-Type Matrix Metalloprotease with Multiple Functions in Diseases. International Journal of Molecular Sciences, 20 (2), 354. doi: http://doi.org/10.3390/ijms20020354

41. Lee, K.-A., Kim, K.-W., Kim, B.-M., Won, J.-Y., Kim, H.-A., Moon, H.-W. et. al. (2018). Clinical and diagnostic significance of serum immunoglobulin A rheumatoid factor in primary Sjogren's syndrome. Clinical Oral Investigations, 23 (3), $1415-$ 1423. doi: http://doi.org/10.1007/s00784-018-2545-4

Received date 04.12.2020

Accepted date 27.12.2020

Published date 30.01.2021

Olga Nedzvetska, MD, Professor, Department of Ophthalmology, Kharkiv Medical Academy of Postgraduate Education, Amosova str., 58, Kharkiv, Ukraine, 61176

E-mail: o.nedzvetska@gmail.com

Irina Bagmut, MD, Professor, Head of Department, Department of Clinical Pathological Physiology, Topographic Anatomy and Operative Surgery, Kharkiv Medical Academy of Postgraduate Education, Amosova str., 58, Kharkiv, Ukraine, 61176

Irina Soboleva, MD, Professor, Department of Ophthalmology, Kharkiv Medical Academy of Postgraduate Education, Amosova str., 58, Kharkiv, Ukraine, 61176

Irina Pastukh, $\mathrm{PhD}$, Associate Professor, Department of Ophthalmology, Kharkiv Medical Academy of Postgraduate Education, Amosova str., 58, Kharkiv, Ukraine, 61176

E-mail: irinapastukh@yahoo.com

Natalia Goncharova, PhD, Associate Professor, Department of Ophthalmology, Kharkiv Medical Academy of Postgraduate Education, Amosova str., 58, Kharkiv, Ukraine, 61176 